\title{
Possibilities of Family Solidarity and Civic Participation of Actors in the Implementation of Social Services of Self-government
}

\section{Bachyncova Giertliova (Daniela Bachyncova Giertliova) ${ }^{1,2}$}

${ }^{1}$ St. ElizabethUniversity of Health and Social Sciences, Bratislava, SK.

${ }^{2}$ St John Neumann Inst, Pribram, CZ.

\section{E-mail address:}

giertliovadaniela@gmail.com

\section{Reprint address:}

Daniela Bachyncova Giertliova

St. ElizabethUniversity of Health and Social Sciences,_Bratislava, SK.

Bratislava

Slovakia

Source: Clinical Social Work and Health Intervention

Pages: $111-113$

Volume: 12

Issue: 3

\section{Reviewers:}

Clauss Muss

I-GAP Zurich, $\mathrm{CH}$

Roberto Cauda

Institute of Infectious Diseases, Catholic University of the Sacred Heart, Rome, IT

\section{Keywords:}

Vitamin D. Hypovitaminosis D. Prevention, Pediatricpatient. Endocrinology.

\section{Publisher:}

International Society of Applied Preventive Medicine i-gap

CSWHI 2021; 12(3): 111 - 113; DOI: 10.22359/cswhi_12_3_19 (C) Clinical Social Work and Health Intervention

\section{Abstract:}

From our point of view, the need for community planning as one of the new possibilities for improving social services in self-government is extremely important. We see the importance and contribution of the planning process for the whole local policy in the active involvement of all citizens and participants in community planning. Only if the citizens are sufficiently informed and involved in the whole process not only community planning makes sense, but also establishing cooperation and creating a network of mutual assistance in the village.

We agree with Demcak (in, Spisiakova, 2011), who states that the strategy of improving social services of each village assumes that local citizens know best how services should be im- proved. The task of the competent is to look for ways to improve their overall quality. Social Services Act 448/2008 Coll. brings the philosophy of quality of social services which lie in 
greater variability; brings new types of services, require skilled workers, services that are closer to the citizens, preferably directly in their natural environment.

\section{OBJECTIVES OF THE SURVEY}

The aim of the survey was to identify opportunities for improvement and enhancement of social services through community planning in the village of Bziny.

We determined the objectives of the survey.

C 1: To find the level of awareness of citizens

Table 1: With the concept of community planning of social services and community plan of the municipality in which I, as a citizen, can participate in the creation of social services:

\begin{tabular}{|c|c|c|}
\hline Options & $\begin{array}{c}\text { Statement } \\
\text { in numbers }\end{array}$ & $\begin{array}{c}\text { Statements } \\
\text { in percentage }\end{array}$ \\
\hline $\begin{array}{c}\text { I've met before } \\
\text { and I know what } \\
\text { it is }\end{array}$ & 16 & $9 \%$ \\
\hline $\begin{array}{c}\text { I've met before } \\
\text { but it's not en- } \\
\text { tirely clear to me }\end{array}$ & 45 & $27 \%$ \\
\hline $\begin{array}{c}\text { I've met before } \\
\text { but it's not en- } \\
\text { tirely clear to me }\end{array}$ & 90 & $54 \%$ \\
\hline I do not care & 17 & $10 \%$ \\
\hline other & - & - \\
\hline together & 168 & $100 \%$ \\
\hline
\end{tabular}

about social services in the village of Bziny.

C 2: Find the perception of citizens or a community plan on which the majority would cooperate would be beneficial.

C 3: Find the relationship between the highest achieved education and the interest of the respondents to actively get involved in community planning.

\section{SURVEY SAMPLE}

We conducted the survey in the village of Bziny. We addressed exclusively the inhabitants of the village of Bziny in order to confirm the goals set by us. The selection of the survey sample from the village of Bziny itself was influenced by many years of work in the local government and also by the knowledge of this locality. Our survey involved 168 respondents, of which 95 were women and 73 men.

Community planning is still an unknown concept for most. From our survey, we found that up to $54 \%$ (90) of respondents answered that they have not yet encountered the concept of community planning and a community plan and do not even know what it is. This concept has already been encountered, but it is not entirely clear to them what it is about $-27 \%$ (45) of respondents.

$10 \%$ (17) of respondents expressed disinterest in this issue and only a small number $9 \%$ (16) of respondents stated that they know what community planning is. The survey shows that if the village is preparing for community planning it will be very important to inform the general public about what community planning is and also about the possibility of involvement of the population.

Table 2: In order to decide which social services a community should provide, I would get involved in community planning

\begin{tabular}{|c|c|c|c|c|c|c|}
\hline Options & $\begin{array}{c}\text { Statement } \\
\text { in numbers: }\end{array}$ & $\begin{array}{c}\text { Statments } \\
\text { in \% }\end{array}$ & $\begin{array}{c}\text { Men in } \\
\text { numbers }\end{array}$ & $\begin{array}{c}\text { Men } \\
\text { in \% }\end{array}$ & $\begin{array}{c}\text { Women } \\
\text { in numbers }\end{array}$ & $\begin{array}{c}\text { Women } \\
\text { in \% }\end{array}$ \\
\hline $\begin{array}{c}\text { I would getactively involved } \\
\text { in decision-making }\end{array}$ & 32 & $19 \%$ & 11 & $15 \%$ & 21 & $22 \%$ \\
\hline $\begin{array}{c}\text { I would rather get involved } \\
\text { than not get involved }\end{array}$ & 97 & $58 \%$ & 28 & $38 \%$ & 69 & $73 \%$ \\
\hline $\begin{array}{c}\text { I would rather not be in- } \\
\text { volved than involved }\end{array}$ & 26 & $15 \%$ & 23 & $32 \%$ & 3 & $3 \%$ \\
\hline I wouldn't get involved at all & 13 & $8 \%$ & 11 & $15 \%$ & 2 & $2 \%$ \\
\hline together & 168 & $100 \%$ & 73 & $100 \%$ & 95 & $100 \%$ \\
\hline
\end{tabular}


We asked the question about the possibility of involving citizens in community planning. First, we present the overall result of the survey, then we divide the answers according to the gender of the respondents.As many as 58\% (97) of all respondents met with the answer that they would be involved rather than not involved in the process; $19 \%$ (32) of respondents said that they would actively participate in community planning; $15 \%$ (26) of respondents say that they would not be involved rather than involved; $8 \%$ (13) would not be involved in the community planning process at all.

Table 3: I see a problem with the possibility to participate in the planning of social services in the municipality:

\begin{tabular}{|c|c|c|}
\hline Options & $\begin{array}{c}\text { Statements } \\
\text { in numbers }\end{array}$ & $\begin{array}{c}\text { Statements } \\
\text { in \% }\end{array}$ \\
\hline In lack of free time & 41 & $24 \%$ \\
\hline $\begin{array}{c}\text { Lack of } \\
\text { information }\end{array}$ & 95 & $57 \%$ \\
\hline $\begin{array}{c}\text { Lack of training } \\
\text { and leadership }\end{array}$ & 19 & $11 \%$ \\
\hline $\begin{array}{c}\text { I wouldn't get } \\
\text { involved }\end{array}$ & 13 & $8 \%$ \\
\hline
\end{tabular}

On this issue, we tried to find out what would prevent citizens from participating in community planning or what they see as a problem. The majority of respondents expressed the opinion that the biggest problem with the possibility of involvement in the planning of social services is the lack of information 57\% (95); lack of free time see as a problem of $24 \%$ (41) respondents; $11 \%$ (19) of respondents believe that the biggest problem of the possibility of involvement could lie in a lack of training and guidance; $8 \%$ (13) of respondents would not participate.

We came to an interesting finding in this question in which the respondents had to express whether the benefit was a community plan in which the majority of citizens would participate. As many as $58 \%$ (97) of respondents think that it would be beneficial for citizens; $27 \%$ (45) of respondents the community plan would not be beneficial; $10 \%$ (17) of respondents could not comment on this topic; $3 \%$ (5) of citizens are convinced that would be beneficial but citizens have to get involved; $2 \%$ (4) respondents did not answer.

\section{RECOMMENDATIONS FOR PRACTICE}

Community planning of social services is a method that seeks to ensure the availability and quality of social services, taking into account the local specifics of the population, their real needs, in accordance with the financial possibilities of self-government.Based on the above results of the survey we propose certain recommendations for the practice in the village of Bziny:

- Approach to community planning in the municipality based on a social analysis of the needs of the population.

- Inform all potential participants in community planning about the whole process.

- Involve all residents and participants in the planning process.

- Provide opportunities to search for new volunteers.

- Involve volunteers as well as students of social work in various activities in the village not only in connection with social services in the village.

- Efforts to create partnerships at the village but also at the inter village level.

- Quality networking of the whole community.

\section{References}

1. SPISIAKOVA $\mathrm{H}$, HOSPODAROVA O, THURZOVA M, DEMCAK D (2011) Local government - basic principles of operation: a guide to the competencies of elected representatives of local government 2010-2014. Presov Education Association Authority, 2011201 s. Self-government education. ISBN 978-80-970616-0-9. 